\title{
LANGUAGE AND DISCOURSE IN ENVIRONMENTAL EDUCATION RESEARCH IN BRAZIL: A BIBLIOGRAPHIC STUDY OF THE EARTE PLATFORM
}

\author{
Rosana Louro Ferreira Silva ${ }^{1}$ \\ José Artur Barroso Fernandes ${ }^{2}$
}

\begin{abstract}
Languages and discourses are a important theme for environmental education field. Following the discuss of subtheme 5 at the $13^{\text {th }}$ Invitational Seminar on Environmental Education Research, this exploratory study in document analysis discusses various aspects of academic production on language and discourse in the Environmental Education (EE). The present research was elaborated from a qualitative and interpretative perspective. The study centers on the analysis of thesis and dissertation abstracts contained in the EArte Project database, an open access digital repository of state of the art EE research in Brazil. Forty abstracts were found, with the words 'language' or 'discourse' in the title: 36 with the word discourse and 4 with language. The results showed that the term 'language' appears infrequently and generally linked to different genres of expression, while the term 'discourse' seems to traverse research in the area in general, found in the titles of works on a diverse range of investigative themes.
\end{abstract}

Keywords: environmental education, state of the art review, language, discourse.

\section{LENGUAJE Y DISCURSO EN LA INVESTIGACIÓN EN EDUCACIÓN AMBIENTAL EN BRASIL: UN ESTUDIO BIBLIOGRÁFICO EN LA PLATAFORMA EARTE}

\section{Resumen}

Lenguajes y discursos son un importante tema para la educación ambiental. A partir de la movilización ocurrida en las discusiones del subtema 5, lenguajes y discursos, del 13th Invitational Seminar on Environmental Education Research, esta investigación es un estudio exploratorio de análisis documental, que tuvo por objetivo comprender las características de las producciones científicas de educación ambiental sobre lenguajes y discursos. Se realizó un estudio cualitativo e interpretativo, a partir del análisis de resúmenes de tesis y disertaciones presentes en el banco de datos del Proyecto EArte, repositorio digital, de acceso público, que reúne producciones académicas ligadas a la educación ambiental. Cuarenta resúmenes fueron encontrados, siendo 36 relacionados a la palabra discurso y cuatro a la palabra lenguaje. Los resultados indican que el término lenguaje aparece poco y, generalmente, ligado a diferentes géneros de expresión, mientras que el término discurso parece tener una transversalidad para la investigación en el área, estando presente en los títulos de trabajos con temáticas de investigación bastante diversificada.

Palabras clave: Educación Ambiental. Estado del Arte. Lenguaje. Discursos.

\footnotetext{
${ }^{1}$ Professora Dra. do Departamento de Zoologia do Instituto de Biociências da USP Email: rosana@usp.br

${ }^{2}$ Professor da Faculdade de Educação da Universidade Federal Fluminense Email: josef@id.uff.br
} 


\title{
LINGUAGEM E DISCURSO NA PESQUISA SOBRE EDUCAÇÃO AMBIENTAL NO BRASIL: ESTUDO BIBLIOGRÁFICO NA PLATAFORMA EARTE
}

\begin{abstract}
Resumo
Linguagens e discursos são um importante tema para a educação ambiental. A partir da mobilização ocorrida nas discussões do subtema 5, linguagens e discursos, do 13th Invitational Seminar on Environmental Education Research, esta pesquisa é um estudo exploratório de análise documental, que teve por objetivo compreender as características das produções científicas de educação ambiental sobre linguagens e discursos. Foi realizado um estudo qualitativo e interpretativo, a partir da análise de resumos de teses e dissertações presentes no banco de dados do Projeto EArte, repositório digital, de acesso público, que reúne produções acadêmicas ligadas à educação ambiental. Quarenta resumos foram encontrados, sendo 36 relacionados à palavra discurso e quatro ao verbete linguagem. Os resultados indicam que o termo linguagem aparece pouco e, geralmente, ligado a diferentes gêneros de expressão, enquanto o termo discurso parece ter uma transversalidade para a pesquisa na área, estando presente nos títulos de trabalhos com temáticas de investigação bastante diversificada.
\end{abstract}

Palavras-chave: Educação ambiental. Estado da arte. Linguagem. Discurso.

\section{Introduction}

In this text we problematize the relations between language, discourse and environmental education, as expressed in the academic production in Environmental Education (EE) in Brazil, based on theoretical contributions from the field and on discussions held at the $13^{\text {th }}$ Invitational Seminar on Environmental Education Research.

Martins et al. (2008) explore the nature of the different discourses that interrogate and constitute the practices of environmental educators, presenting the central ideas of critical discourse studies and reflections on the relations between research in the field of Environmental Education and Science Education,

In the international context, Berryman and Sauvé (2012) argue that 'language and discourse' are fundamental dimensions of environmental education.

Browsing research journals in education and environmental education reveal the weight of language as part of a research problematic or as an object of research, directly as 'language' or 'discourse,' or through associated themes such as 'voice,' 'story,' 'metaphor,' 'rhetoric,' 'literacy,' 'text,' 'writing,' 'reading,' 'defining' and 'debating.'

We share the authors' idea that language and discourse are not spontaneously given but social constructs, "dialectically related to action and history, giving shape to a culture and being shaped by a culture" (BERRYMAN \& SAUVÉ 2012: 141).

One example is the authors' concern over the term Education for Sustainable Development (ESD), proposed by UNESCO as a substitute for Environmental Education (EE). This is also a polemical issue in the field of research and is closely linked to the discourse used both by UNESCO and by Latin American researchers, who emphasize the importance of retaining the term Environmental Education. As a question it thus strongly pervades the differences in the languages and discourses employed by the two 'currents,' as Berryman and Sauvé stress (2012):

However, the point here is not the issue of change in itself, nor is it the issue of the language and discourse in itself, but the dynamic and dialectic relationship that are being played out in environmental education between 
language, discourse, and practice. Language and discourse bear some meaning, direction, intent and they orient or focus attention, perception and action that also feedback on language and discourse. (BERRYMAN \& SAUVÉ, 2012: 134).

For Loureiro (2012), in accord with the critical tradition, the premises for a sustainable society are materialized through social movements and through collective and everyday actions that seek to break away from current patterns of sociability.

The critical current of Environmental Education, as described by Sauvé (2005),

...insists, essentially, on the analysis of the social dynamics that underlie real world environmental situations and problematics: the analysis of the intentions, positions, arguments, explicit and implicit values, decisions and actions of the different protagonists in any given situation. (SAUVÉ 2005: $30)$.

For critical Environmental Education, a concern with language and discourses, and their influences on pedagogical praxis, is essential due to the dialogical dimension inherent to this approach.

Given the above, the importance of the relations between discourse and environmental education for the area becomes clear. However our question is how this theme might be expressed the field of research. Our hypothesis is that the abstracts of theses and dissertations available in the EArte database can help us understand the depth of the theme's exploration in the EE field in Brazil, its theoretical and methodological relations, and the main topics where these elements are investigated. In this way, publications that guide and justify the research are mentioned. The decision to explore these materials is based on our understanding that they constitute "a historical and political production, insofar as words are also constructs and insofar as language is also constitutive of practices" (FISCHER, 2001).

\section{Objectives}

The research question informing the present study is: how have the terms language and discourse permeated the research the research in Brazilian Environmental Education?

Setting out from this question, we define the following objectives:

- to identify the frequency and meanings that the terms Language and Discourse assumed in the environmental education research, through the analysis of thesis and dissertation abstracts in the Earte (State of the Art of Research in Environmental Education) database.

- to identify the distribution of this production from 1981 to 2012 in Brazilian Environmental Education;

- to identify trends in the field vis-à-vis the terms Language and Discourse, with respect to the theme of the study, the methodological procedures most frequently adopted and the main theoretical framework used, seeking to map trends.

\section{Methodological procedures}

The present research was elaborated from a qualitative and interpretative perspective, seeking to describe categories relating to the analyzed documents. In terms of research methodology, this investigation is an appraisal of the state of the art, which, as formulated by Romanoswski and Ens (2006), signifies conducting "a mapping process that uncovers and examines the knowledge already produced and identify the approaches used, the topics most frequently researched and the existing lacunae." 
In this sense, our approach is exploratory in kind, in line with an investigation into the field's state of the art, presenting a descriptive methodology that, by mapping and discussing a particular area of academic production, seeks to determine which aspects and dimensions are being highlighted and foregrounded in different times and places (FERREIRA, 2002).

Diverse authors have emphasized the importance of developing research in this area with the aim of deepening knowledge of a specific field and signposting potential gaps and areas of interest where future studies can enrich the accumulated body of knowledge (ROMANOWSKI \& ENS, 2006; REIGOTA, 2007).

Our decision to study the production of theses and dissertations matches the argument advanced by Marini and Megid Neto (2011: 561) that these documents are more appropriate for state of the art research studies, "since they constitute primary documents and complete reports of the studies undertaken, which, as a rule, are subsequently presented in a succinct manner in articles or at events (congresses, symposia, etc.)."

The bibliographic data for this study was assembled using the EArte database, a research project that makes available a platform for searching a database containing theses and dissertations that connect environmental themes to education processes (available at: www.earte.net), based on classifications elaborated by the research group itself. The objectives of the EArte project include compiling an archive of the dissertations and theses on Environmental Education developed in Brazil and conducting descriptive and analytic studies concerning this production. The project has been developed in collaboration with researchers from various universities and has become an important space for enabling different mappings of the academic production in the EE area in the country.

It is important to emphasize that the EArte database selects and classifies this literature through an analysis of the abstracts of theses and dissertations, an approach shared by our own investigation. Analyzing abstracts, rather than complete texts, allows the possibility of examining a large range of works - which is attractive for an exploratory work such as the present study. On the other hand, though, it precludes more in-depth readings suitable to developing more specific analyses on a smaller set of academic output.

The research was carried out in June 2016 and the quantitative data consulted again in August 2016, taking into account that the database is continuously fed with the new works to which the team has access. At the moment of our data collection, the database covered texts produced between 1981 and 2012, with the exception of 2010 when there was an interruption in the CAPES Theses and Dissertations Database, the main source of information for the EArte database.

To assemble the corpus of our work, the search terms utilized in the EArte system were 'language' and 'discourse.' Searches were undertaken in two ways: a word search in the title field, and a word search in the abstract field. The results returned for these searches were compared with the total production of the area and organized in tables.

We observed that the results from the word search in the abstract field returned a large number of works where the terms were used in a much wider context, such as, for example, works that contained the term 'language' in relation to computer language in studies on digital educational resources. Given the polysemy presented by the search terms used, we decided to limit our analysis to the results of the word search in the title field.

Next, in order to organize the data corpus in a way that would allow us to develop our analysis, we printed out the records for all 40 works identified by the searches. These were then categorized using the 'study theme' descriptor from the classificatory schema developed by the EArte team. In the project's classifications, the 'study theme' descriptor specifies the "theme or topic studied in the work, generally linked to the research problem/objective, but not corresponding to the object of investigation per se. It comprises the main or privileged study theme," as presented on the project website (www.earte.net). 
Subsequently, based on our readings, the methodological procedures and theoretical frameworks used by the studies were identified in the body of the abstract, building a table for the term 'language' and another for the term 'discourse.' Due to the high number of works related to the term 'discourse,' we also analyzed these in relation to the space/subject of production of discourses and also in relation to the meanings attributed to the term in the title, enabling a clearer definition of its polysemy.

\section{Results and discussion}

The results show the presence of the terms 'language' and 'discourse' in all periods of the environmental education research, with significant increase over the years. In Table 1 we show the data on the works published in the EArte database during four decades, based on the search terms 'language' and 'discourse' in two situations: identifying works in which the term is present in the title, or works that contain the word in the abstract. This dates was compared with total production of the database.

Table 1 - Quantitative data on the presence of the terms 'language' and 'discourse' based on time filters and search field. (Source: earte.net)

\begin{tabular}{|l|l|l|l|l|l|}
\hline Period & $\begin{array}{l}\text { Total } \\
\text { production } \\
\text { selected in the } \\
\end{array}$ & & \multicolumn{2}{l|}{ Word in the title only } & \multicolumn{2}{l|}{ Word in the abstract } \\
\cline { 3 - 6 } & Language & Discourse & Language & Discourse \\
\hline $\mathbf{1 9 8 0 - 1 9 9 0}$ & 20 & 0 & 1 & 0 & 1 \\
\hline $\mathbf{1 9 9 1 - 2 0 0 0}$ & 352 & 0 & 3 & 6 & 28 \\
\hline $\mathbf{2 0 0 1 - 2 0 0 9}$ & 1737 & 2 & 25 & 51 & 164 \\
\hline $\mathbf{2 0 1 1 - 2 0 1 2}$ & 654 & 2 & 7 & 20 & 69 \\
\hline TOTAL & $\mathbf{2 7 6 3}$ & $\mathbf{4}$ & $\mathbf{3 6}$ & $\mathbf{7 7}$ & $\mathbf{2 6 2}$ \\
\hline
\end{tabular}

The tabulated data enables us to observe that, for the abstract field, the terms 'language' and 'discourse' are present in $2.9 \%$ and $9.8 \%$ of works, respectively, with these percentages remaining more or less constant over the years studied.

Tables 2 and 3 were produced using the Study Theme descriptor in the EArte database, as mentioned in the Methodology section, based solely on the data containing the words 'language' (Table 2) and 'discourse' (Table 3) in the title. Abstracts were analyzed to determine which methodological procedures and primary theoretical frameworks were used. The data present in the forty abstracts were then summarized and presented as follows: 
Table 2 - Qualitative data referring to the word 'language' in the title field. (Source: elaborated from the EArte database)

\begin{tabular}{|c|c|c|c|c|}
\hline No. & Title of Work ${ }^{3}$ & Study Theme & $\begin{array}{l}\text { Methodological } \\
\text { Procedures }\end{array}$ & $\begin{array}{l}\text { Theoretical } \\
\text { Framework }\end{array}$ \\
\hline 1 & $\begin{array}{l}\text { A interface meio ambiente e linguagem: uma } \\
\text { proposta de educação ambiental por meio do } \\
\text { trabalho com a leitura (The interface of the } \\
\text { environment and language: a proposal of } \\
\text { environmental education with reading) }\end{array}$ & $\begin{array}{lr}\text { Work } & \text { and } \\
\text { Training } & \text { of } \\
\text { Academic } & \text { Staff } \\
\text { /Agents } & \end{array}$ & $\begin{array}{l}\text { questionnaires, } \\
\text { intervention }\end{array}$ & $\begin{array}{l}\text { not indicated } \\
\text { in abstract }\end{array}$ \\
\hline 2 & $\begin{array}{l}\text { Linguagem cartográfica e Geografia } \\
\text { integrando forma e conteúdo na construção } \\
\text { da responsabilidade ambiental: uma } \\
\text { experiência metodológica vivida com adultos } \\
\text { em fase de alfabetização (Cartographic } \\
\text { language and geography integrating form and } \\
\text { content in the construction of environmental } \\
\text { responsibility: a methodological experience } \\
\text { with adults in the literacy) }\end{array}$ & $\begin{array}{ll}\text { Teaching } & \text { and } \\
\text { Learning } & \\
\text { Processes } & \text { and } \\
\text { Methods } & \end{array}$ & $\begin{array}{l}\text { educational } \\
\text { intervention }\end{array}$ & $\begin{array}{l}\text { not indicated } \\
\text { in abstract }\end{array}$ \\
\hline 3 & $\begin{array}{l}\text { Desenhar é preciso: um estudo sobre a } \\
\text { contribuição da linguagem do desenho como } \\
\text { um fazer educação ambiental (To design is } \\
\text { necessary: a study on the contribution of the } \\
\text { language of drawing as environmental } \\
\text { education) }\end{array}$ & $\begin{array}{ll}\text { Teaching } & \text { and } \\
\text { Learning } & \\
\text { Processes } & \text { and } \\
\text { Methods } & \end{array}$ & $\begin{array}{l}\text { educational } \\
\text { intervention }\end{array}$ & $\begin{array}{l}\text { not indicated } \\
\text { in abstract }\end{array}$ \\
\hline 4 & $\begin{array}{l}\text { O papel da sensibilidade e da linguagem } \\
\text { poética nos processos formativos em } \\
\text { Educação Ambiental - uma ciranda multicor } \\
\text { (The role of sensibility and poetic language in } \\
\text { the formative processes in Environmental } \\
\text { Education) }\end{array}$ & $\begin{array}{l}\text { Work and } \\
\text { Training of } \\
\text { Teachers/Agents }\end{array}$ & $\begin{array}{l}\text { educational } \\
\text { intervention }\end{array}$ & $\begin{array}{l}\text { not indicated } \\
\text { in abstract }\end{array}$ \\
\hline
\end{tabular}

Examining the data in the table, we can observe that the four works referring to 'language' in the title are associated with different kinds of expression: literary, cartographic, artistic and poetic. The methodological procedures of the four works are related to analyses of educational interventions conducted using these forms of expression and none of the abstracts indicates the main theoretical framework employed.

The number of works with the word 'discourse' in the title is much higher, 36 works in total, the main characteristics of which detailed in Table 3:

Table 3 - Qualitative data referring to the word 'discourse' in the title field. (Source: elaborated from the EArte database)

\begin{tabular}{|l|l|l|l|l|}
\hline $\mathbf{N}^{\mathbf{0}}$ & Title of Work & Study Theme & $\begin{array}{l}\text { Methodological } \\
\text { Procedures }\end{array}$ & $\begin{array}{l}\text { Theoretical } \\
\text { Framework }\end{array}$ \\
\hline $\mathbf{1}$ & $\begin{array}{l}\text { Representações de corpos e seus discursos: } \\
\text { pintando a tela a partir dos olhares dos(as) } \\
\text { acadêmicos(as) de Educação Física } \\
\text { (Representations of bodies and their } \\
\text { discourses: painting the screen from the looks } \\
\text { of the Physical Education students) }\end{array}$ & $\begin{array}{l}\text { Representations } \\
\text { an Cognitive } \\
\text { Processes of the } \\
\text { Trainee in EE }\end{array}$ & $\begin{array}{l}\text { Focus groups } \\
\text { Narratives } \\
\text { fultural studies } \\
\text { post- } \\
\text { structuralist } \\
\text { perspective }\end{array}$ \\
\hline $\mathbf{2}$ & $\begin{array}{l}\text { A gestão ambiental entre o discurso } \\
\text { legitimador e práticas instrumentais (The } \\
\text { environmental management between the } \\
\text { legitimating discourse and instrumental } \\
\text { practices) }\end{array}$ & $\begin{array}{l}\text { Conceptions, } \\
\text { Representations } \\
\text { and Cognitive } \\
\text { Processes of the } \\
\text { Instructor in EE }\end{array}$ & $\begin{array}{l}\text { Document } \\
\text { analysis } \\
\text { Semi-structured } \\
\text { interview }\end{array}$ & $\begin{array}{l}\text { Not indicated in } \\
\text { the abstract }\end{array}$ \\
\hline
\end{tabular}

\footnotetext{
${ }^{3}$ We chose to keep the original title in Portuguese in the tables for not to mischaracterize it, but we bring the translation of the meaning in parentheses
} 


\begin{tabular}{|c|c|c|c|c|}
\hline 3 & $\begin{array}{l}\text { Conflitos ideológicos no texto da Lei } \\
\text { 9.795/99: uma análise do discurso ideológico } \\
\text { no texto da lei de educação ambiental } \\
\text { (Ideological conflicts in the text of Law } 9.795 \\
\text { / 99: an analysis of the ideological discourse } \\
\text { in the environmental education law) }\end{array}$ & $\begin{array}{l}\text { Public Policies in } \\
\text { EE }\end{array}$ & $\begin{array}{l}\text { Document } \\
\text { analysis }\end{array}$ & $\begin{array}{l}\text { Discourse } \\
\text { analysis }\end{array}$ \\
\hline 4 & $\begin{array}{l}\text { Às margens do discurso verde (On the } \\
\text { margins of green discourse) }\end{array}$ & Communication & $\begin{array}{l}\text { Document } \\
\text { analysis }\end{array}$ & $\begin{array}{l}\text { Post- } \\
\text { structuralist } \\
\text { theoretical } \\
\text { premises }\end{array}$ \\
\hline 5 & $\begin{array}{l}\text { A ética no discurso do jornal Zero Hora sobre } \\
\text { as mudanças climáticas (Ethics in the Zero } \\
\text { Hora newspaper's discourse about climate } \\
\text { change) }\end{array}$ & Communication & $\begin{array}{l}\text { Document } \\
\text { analysis }\end{array}$ & $\begin{array}{l}\text { Depth } \\
\text { hermeneutics }\end{array}$ \\
\hline 6 & $\begin{array}{l}\text { O discurso do sujeito coletivo e a } \\
\text { representação social do Parque Natural } \\
\text { Municipalda } \\
\text { Freguesia: o que os amigos do bosque } \\
\text { contam? (The discourse of the collective } \\
\text { subject and the social representation of the } \\
\text { Parque natural Municipal da Freguesia: what } \\
\text { do forest friends count?) }\end{array}$ & $\begin{array}{l}\text { Conceptions, } \\
\text { Representations } \\
\text { and Cognitive } \\
\text { Processes of the } \\
\text { Trainee in EE }\end{array}$ & - & $\begin{array}{l}\text { Discourse of the } \\
\text { collective } \\
\text { subject }\end{array}$ \\
\hline 7 & $\begin{array}{l}\text { Educação Ambiental: concepções e discursos } \\
\text { dos profissionais do ensino fundamental, de } 1^{a} \\
a 4^{a} \text { série, nas escolas confessionais de } \\
\text { Manaus } \\
\text { (Environmental Education: conceptions and } \\
\text { discourses of }, 1^{\text {st }} \text { to } 4^{\text {th }} \text { grade teachers in a } \\
\text { confessional schools of Manaus) }\end{array}$ & $\begin{array}{l}\text { Conceptions, } \\
\text { Representations } \\
\text { and Cognitive } \\
\text { Processes of the } \\
\text { Instructor in EE }\end{array}$ & - & - \\
\hline 8 & $\begin{array}{l}\text { Discursos de professores sobre a Amazônia: } \\
\text { contribuições para um ensino de Ciências em } \\
\text { busca da sustentabilidade (Teachers' } \\
\text { discourses about Amazônia: contributions to } \\
\text { science teaching to sustainability) }\end{array}$ & $\begin{array}{l}\text { Conceptions, } \\
\text { Representations } \\
\text { and Cognitive } \\
\text { Processes of the } \\
\text { Instructor in EE }\end{array}$ & $\begin{array}{l}\text { Case study } \\
\text { Semi-structured } \\
\text { interview }\end{array}$ & $\begin{array}{l}\text { Discourse } \\
\text { analysis from } \\
\text { the French } \\
\text { perspective }\end{array}$ \\
\hline 9 & $\begin{array}{l}\text { O discurso sobre o ensino de Design levando } \\
\text { em consideração aspectos ambientais (The } \\
\text { discourse on the teaching of Design taking } \\
\text { environmental aspects) }\end{array}$ & $\begin{array}{l}\text { Curricula, } \\
\text { Programs and } \\
\text { Projects }\end{array}$ & $\begin{array}{l}\text { Document } \\
\text { analysis }\end{array}$ & $\begin{array}{l}\text { Not indicated in } \\
\text { the abstract }\end{array}$ \\
\hline 10 & $\begin{array}{l}\text { As vozes dos que vivem à margem dos rios } \\
\text { urbanos: uma análise do contexto } \\
\text { socioambiental da ocupação urbana, através } \\
\text { dos } \\
\text { discursos da população (The voices of those } \\
\text { living on the fringes of urban rivers: an } \\
\text { analysis of the socio-environmental context of } \\
\text { urban occupancy through discourses of the } \\
\text { population) }\end{array}$ & $\begin{array}{l}\text { Conceptions, } \\
\text { Representations } \\
\text { and Cognitive } \\
\text { Processes of the } \\
\text { Trainee in EE }\end{array}$ & $\begin{array}{l}\text { Interviews } \\
\text { Analysis } \\
\text { content } \\
\text { Statistical } \\
\text { analysis } \\
\text { (Alceste) }\end{array}$ & $\begin{array}{l}\text { Not indicated in } \\
\text { the abstract }\end{array}$ \\
\hline 11 & $\begin{array}{l}\text { As concepções de educação ambiental } \\
\text { subjacentes aos discursos docentes e } \\
\text { discentes: do arcabouço jurídico ao cotidiano } \\
\text { (The conceptions of environmental education } \\
\text { of the teaching discourses and students: from } \\
\text { the legal framework to the daily life) }\end{array}$ & $\begin{array}{l}\text { Conceptions, } \\
\text { Representations } \\
\text { and Cognitive } \\
\text { Processes of the } \\
\text { Trainee in EE } \\
\text { Conceptions, } \\
\text { Representations } \\
\text { and Cognitive } \\
\text { Processes of the } \\
\text { Instructor in EE } \\
\text { Work and } \\
\text { Training of }\end{array}$ & $\begin{array}{l}\text { Questionnaires } \\
\text { distributed to } \\
\text { academic staff }\end{array}$ & $\begin{array}{l}\text { Not indicated in } \\
\text { the abstract }\end{array}$ \\
\hline
\end{tabular}




\begin{tabular}{|c|c|c|c|c|}
\hline & & $\begin{array}{l}\text { Academic } \\
\text { Staff/Agents }\end{array}$ & & \\
\hline 12 & $\begin{array}{l}\text { Conhecer para colonizar/colonizar para } \\
\text { conhecer: a natureza do discurso do } \\
\text { ecoturismo (To know to colonize / colonize to } \\
\text { know: the nature of ecotourism discourse) }\end{array}$ & Communication & $\begin{array}{l}\text { Document } \\
\text { analysis }\end{array}$ & Cultural studies \\
\hline 13 & $\begin{array}{l}\text { Territorialidades em luta - uma análise dos } \\
\text { discursos ecológicos (Territorialities in } \\
\text { struggle - an analysis of ecological discourses) }\end{array}$ & $\begin{array}{l}\text { Foundations of } \\
\text { EE }\end{array}$ & $\begin{array}{l}\text { Analysis of } \\
\text { statements by } \\
\text { government } \\
\text { institutions and } \\
\text { sectors of the } \\
\text { ecological } \\
\text { movement }\end{array}$ & $\begin{array}{l}\text { Not indicated in } \\
\text { the abstract }\end{array}$ \\
\hline 14 & $\begin{array}{l}\text { Projetos de Educação Ambiental } \\
\text { desenvolvidos na escola: um estudo do } \\
\text { discurso de alunos da Educação Básica } \\
\text { (Environmental Education Projects developed } \\
\text { at school: a study of students' discourse of } \\
\text { Basic Education) }\end{array}$ & $\begin{array}{l}\text { Curricula, } \\
\text { Programs and } \\
\text { Projects } \\
\text { Conceptions, } \\
\text { Representations } \\
\text { and Cognitive } \\
\text { Processes of the } \\
\text { Trainee in EE }\end{array}$ & $\begin{array}{l}\text { Case study } \\
\text { Observation } \\
\text { Interviews } \\
\text { Semi-structured } \\
\text { questionnaires }\end{array}$ & $\begin{array}{l}\text { Critical and } \\
\text { emancipatory } \\
\text { Environmental } \\
\text { Education }\end{array}$ \\
\hline 15 & $\begin{array}{l}\text { Consumo e técnica no discurso ambiental: da } \\
\text { prótese ao ideal de sustentabilidade } \\
\text { (Consumption and technique in environmental } \\
\text { discourse: from prosthesis to the ideal of } \\
\text { sustainability) }\end{array}$ & Communication & $\begin{array}{l}\text { Not indicated in } \\
\text { the abstract }\end{array}$ & $\begin{array}{l}\text { Thought of the } \\
\text { philosophers } \\
\text { Jean Baudrillard } \\
\text { and Umberto } \\
\text { Galimberti and } \\
\text { the } \\
\text { psychoanalyst } \\
\text { Gláucia Dunley }\end{array}$ \\
\hline 16 & $\begin{array}{l}\text { Discurso sobre Educação Ambiental em } \\
\text { Geografia da } 10^{a} \text { classe no âmbito da defesa e } \\
\text { conservação da natureza em Moçambique } \\
\text { (Discourse on Environmental Education in } \\
\text { Geography of the 10th class in the } \\
\text { nature conservation in Mozambique) }\end{array}$ & $\begin{array}{l}\text { Curricula, } \\
\text { Programs and } \\
\text { Projects } \\
\text { Conceptions, } \\
\text { Representations } \\
\text { and Cognitive } \\
\text { Processes of the } \\
\text { Instructor in EE } \\
\text { Conceptions, } \\
\text { Representations } \\
\text { and Cognitive } \\
\text { Processes of the } \\
\text { Trainee in EE }\end{array}$ & $\begin{array}{l}\text { Document } \\
\text { analysis } \\
\text { Interviews } \\
\text { Questionnaires }\end{array}$ & $\begin{array}{l}\text { Not indicated in } \\
\text { the abstract }\end{array}$ \\
\hline 17 & $\begin{array}{l}\text { O currículo e o discurso de professores e } \\
\text { alunos do curso de Geografia sobre espaço } \\
\text { geográfico, meio ambiente e preservação dos } \\
\text { mananciais (The curriculum and the discourse } \\
\text { of teachers and students of the Geography } \\
\text { course about geographic space, environment } \\
\text { and water conservation) }\end{array}$ & $\begin{array}{l}\text { Curricula, } \\
\text { Programs and } \\
\text { Projects } \\
\text { Conceptions, } \\
\text { Representations } \\
\text { and Cognitive } \\
\text { Processes of the } \\
\text { Instructor in EE } \\
\text { Conceptions, } \\
\text { Representations } \\
\text { and Cognitive } \\
\text { Processes of the } \\
\text { Trainee in EE }\end{array}$ & Questionnaire & $\begin{array}{l}\text { Not indicated in } \\
\text { the abstract }\end{array}$ \\
\hline 18 & $\begin{array}{l}\text { Análise crítica dos discursos presentes nos } \\
\text { documentos que definem a política de } \\
\text { educação ambiental no Brasil (Critical }\end{array}$ & $\begin{array}{l}\text { Public Policies in } \\
\text { EE }\end{array}$ & $\begin{array}{l}\text { Document } \\
\text { analysis }\end{array}$ & $\begin{array}{l}\text { Historical- } \\
\text { dialectical } \\
\text { materialism, }\end{array}$ \\
\hline
\end{tabular}




\begin{tabular}{|c|c|c|c|c|}
\hline & $\begin{array}{l}\text { analysis of the discourses present in the } \\
\text { documents that define the policy of } \\
\text { environmental education in Brazil) }\end{array}$ & & & $\begin{array}{l}\text { Critical } \\
\text { Environmental } \\
\text { Education, } \\
\text { Critical } \\
\text { discourse } \\
\text { analysis } \\
\end{array}$ \\
\hline 19 & $\begin{array}{l}\text { A questão do formalismo no discurso oficial } \\
\text { da Educação Ambiental (The issue of } \\
\text { formalism in the official discourse of } \\
\text { Environmental Education) }\end{array}$ & $\begin{array}{l}\text { Public Policies in } \\
\text { EE }\end{array}$ & $\begin{array}{l}\text { Document } \\
\text { analysis }\end{array}$ & $\begin{array}{l}\text { Not indicated in } \\
\text { the abstract }\end{array}$ \\
\hline 20 & $\begin{array}{l}\text { O discurso ambiental na comunicação de } \\
\text { massa: um estudo da Conferência das Nações } \\
\text { Unidas sobre o Meio Ambiente e } \\
\text { Desenvolvimento (Environmental discourse in } \\
\text { mass communication: a study of the United } \\
\text { Nations Conference on Sustainable } \\
\text { Development) }\end{array}$ & Communication & $\begin{array}{l}\text { Document } \\
\text { analysis } \\
\text { (newspapers } \\
\text { and TV news } \\
\text { programs) }\end{array}$ & $\begin{array}{l}\text { Not indicated in } \\
\text { the abstract }\end{array}$ \\
\hline 21 & $\begin{array}{l}\text { O estudo da eficácia da Educação Ambiental } \\
\text { formal à luz da análise do discurso (The study } \\
\text { of the effectiveness of formal environmental } \\
\text { education by discourse analysis) }\end{array}$ & $\begin{array}{l}\text { Curricula, } \\
\text { Programs and } \\
\text { Projects }\end{array}$ & Interviews & $\begin{array}{l}\text { Modern } \\
\text { linguistic theory }\end{array}$ \\
\hline 22 & $\begin{array}{l}\text { A temática ambiental nas séries iniciais do } \\
\text { ensino fundamental: concepções reveladas no } \\
\text { discurso de professoras sobre sua prática } \\
\text { (The environmental theme in the initial grades } \\
\text { of elementary school: conceptions revealed in } \\
\text { the teachers' discourse about their practice) }\end{array}$ & $\begin{array}{l}\text { Conceptions, } \\
\text { Representations } \\
\text { and Cognitive } \\
\text { Processes of the } \\
\text { Instructor in EE }\end{array}$ & Interviews & $\begin{array}{l}\text { Not indicated in } \\
\text { the abstract }\end{array}$ \\
\hline 23 & $\begin{array}{l}\text { Discurso educativo e apropriação do meio } \\
\text { ambiente na área de um grande projeto de } \\
\text { investimento: o caso UHE-Tucuruí, PA } \\
\text { (Educational discourse and appropriation of } \\
\text { the environment in a big investment project: } \\
\text { the case UHE-Tucuruí, PA) }\end{array}$ & $\begin{array}{l}\text { Curricula, } \\
\text { Programs and } \\
\text { Projects }\end{array}$ & $\begin{array}{l}\text { Not indicated in } \\
\text { the abstract }\end{array}$ & $\begin{array}{l}\text { Not indicated in } \\
\text { the abstract }\end{array}$ \\
\hline 24 & $\begin{array}{l}\text { A ordem do discurso da Educação Ambiental } \\
\text { (The order of the discourse of Environmental } \\
\text { Education) }\end{array}$ & $\begin{array}{l}\text { Organization of } \\
\text { School Institution }\end{array}$ & $\begin{array}{l}\text { Statements } \\
\text { given by } \\
\text { academic staff } \\
\text { and historical } \\
\text { narratives of the } \\
\text { environmentalis } \\
\text { t movement }\end{array}$ & $\begin{array}{l}\text { Post- } \\
\text { structuralist } \\
\text { perspective }\end{array}$ \\
\hline 25 & $\begin{array}{l}\text { Discurso ambientalista na Educação } \\
\text { Ambiental e a legislação ambiental brasileira } \\
\text { (Environmental Discourse in Environmental } \\
\text { Education and Brazilian Environmental Law) }\end{array}$ & $\begin{array}{l}\text { Conceptions, } \\
\text { Representations } \\
\text { and Cognitive } \\
\text { Processes of the } \\
\text { Instructor in EE } \\
\text { Foundations of } \\
\text { EE }\end{array}$ & Interviews & Hermeneutics \\
\hline 26 & $\begin{array}{l}\text { Da lógica dicotomizante a busca de novos } \\
\text { paradigmas: o discurso de pesquisadores } \\
\text { ambientais do Rio de Janeiro (From } \\
\text { dichotomizing logic to the search for new } \\
\text { paradigms: the discourse of environmental } \\
\text { researchers from Rio de Janeiro) }\end{array}$ & $\begin{array}{l}\text { Conceptions, } \\
\text { Representations } \\
\text { and Cognitive } \\
\text { Processes of the } \\
\text { Instructor in EE }\end{array}$ & $\begin{array}{l}\text { Not indicated in } \\
\text { the abstract }\end{array}$ & $\begin{array}{l}\text { Not indicated in } \\
\text { the abstract }\end{array}$ \\
\hline 27 & $\begin{array}{l}\text { Paradigmas sanitários e problemas } \\
\text { ambientais: os discursos dos agentes } \\
\text { comunitários de saúde (Health paradigms and } \\
\text { environmental problems: the discourses of } \\
\text { community health agentes) }\end{array}$ & $\begin{array}{l}\text { Conceptions, } \\
\text { Representations } \\
\text { and Cognitive } \\
\text { Processes of the } \\
\text { Trainee in EE }\end{array}$ & $\begin{array}{l}\text { Semi-structured } \\
\text { interviews }\end{array}$ & $\begin{array}{l}\text { Discourse of the } \\
\text { collective } \\
\text { subject }\end{array}$ \\
\hline 28 & Avaliação da influência do discurso ambiental & Organization of & Case study & Not indicated in \\
\hline
\end{tabular}




\begin{tabular}{|c|c|c|c|c|}
\hline & $\begin{array}{l}\text { curricular das comunidades locais do distrito } \\
\text { de Dondo-Moçambique (Evaluation of the } \\
\text { influence of the curricular environmental } \\
\text { discourse of the local communities of the } \\
\text { district of Dondo-Mozambique) }\end{array}$ & School Institution & & the abstract \\
\hline 29 & $\begin{array}{l}\text { A temática ambiental no discurso da } \\
\text { Companhia Vale do Rio Doce: jornal Vale } \\
\text { Notícias-Minas (The environmental theme in } \\
\text { the speech of Companhia Vale do Rio Doce: } \\
\text { Vale Notícias-Minas newspaper) }\end{array}$ & Communication & $\begin{array}{l}\text { Document } \\
\text { analysis } \\
\text { (newspapers) }\end{array}$ & $\begin{array}{l}\text { Not indicated in } \\
\text { the abstract }\end{array}$ \\
\hline 30 & $\begin{array}{l}\text { Lixo sujo e lixo limpo - o discurso social } \\
\text { sobre o lixo (Dirty trash and clean trash - the } \\
\text { social discourse about trash) }\end{array}$ & $\begin{array}{l}\text { Conceptions, } \\
\text { Representations } \\
\text { and Cognitive } \\
\text { Processes of the } \\
\text { Trainee in EE }\end{array}$ & $\begin{array}{l}\text { Not indicated in } \\
\text { the abstract }\end{array}$ & $\begin{array}{l}\text { Psychosocial } \\
\text { approach }\end{array}$ \\
\hline 31 & $\begin{array}{l}\text { O discurso da Agenda 21: recursos hídricos e } \\
\text { a Educação Ambiental na escola (The } \\
\text { discourse of Agenda 21: water resources and } \\
\text { Environmental Education in the school) }\end{array}$ & $\begin{array}{l}\text { Curricula, } \\
\text { Programs and } \\
\text { Projects }\end{array}$ & $\begin{array}{l}\text { Document } \\
\text { analysis }\end{array}$ & $\begin{array}{l}\text { Sociosemiotics } \\
\text { and semiotics of } \\
\text { cultures }\end{array}$ \\
\hline 32 & $\begin{array}{l}\text { Uma floresta tocada apenas por homens } \\
\text { puros... ou do que aprendemos com os } \\
\text { discursos contemporâneos sobre a Amazônia } \\
\text { (A forest played only by pure men ... or what } \\
\text { we learn from the contemporary discourses on } \\
\text { the Amazon) }\end{array}$ & $\begin{array}{l}\text { Foundations of } \\
\text { EE }\end{array}$ & $\begin{array}{l}\text { Document } \\
\text { analysis } \\
\text { (newspapers) }\end{array}$ & Cultural studies \\
\hline 33 & $\begin{array}{l}\text { Tecnologias e educação ambiental: o discurso } \\
\text { coletivo na formaça docente (Technologies } \\
\text { and environmental education: the collective } \\
\text { discourse in teacher education) }\end{array}$ & $\begin{array}{lr}\text { Didactic } & \\
\text { Resources } & \\
\text { Work } & \text { and } \\
\text { Training } & \text { of } \\
\text { Academic } & \text { Staff } \\
\text { /Agents } & \\
\end{array}$ & $\begin{array}{l}\text { Analysis of the } \\
\text { logbooks of } \\
\text { academic staff }\end{array}$ & $\begin{array}{l}\text { Discourse of the } \\
\text { collective } \\
\text { subject } \\
\text { Lefévre and } \\
\text { Lefévre }\end{array}$ \\
\hline 34 & $\begin{array}{l}\text { A Educação Ambiental na Pampulha: entre o } \\
\text { discurso e a prática (Environmental } \\
\text { Education in Pampulha: between discourse } \\
\text { and practice) }\end{array}$ & $\begin{array}{l}\text { Curricula, } \\
\text { Programs and } \\
\text { Projects }\end{array}$ & Case study & $\begin{array}{l}\text { Not indicated in } \\
\text { the abstract }\end{array}$ \\
\hline 35 & $\begin{array}{l}\text { A produtividade do discurso da } \\
\text { sustentabilidade nas instituições financeiras: } \\
\text { desafios para a Educação Ambiental } \\
\text { contemporânea (The productivity of } \\
\text { sustainability discourse in financial } \\
\text { institutions: challenges for contemporary } \\
\text { Environmental Education) }\end{array}$ & Communication & $\begin{array}{l}\text { Document } \\
\text { analysis }\end{array}$ & $\begin{array}{l}\text { Not indicated in } \\
\text { the abstract }\end{array}$ \\
\hline 36 & $\begin{array}{l}\text { A temática ambiental: concepções reveladas } \\
\text { no discurso de acadêmicos-professores (séries } \\
\text { iniciais do ensino fundamental) sobre sua } \\
\text { prática (The environmental theme: } \\
\text { conceptions revealed in the discourse of } \\
\text { academic-teachers of the elementary school } \\
\text { about their practice) }\end{array}$ & $\begin{array}{l}\text { Conceptions, } \\
\text { Representations } \\
\text { and Cognitive } \\
\text { Processes of the } \\
\text { Trainee in EE }\end{array}$ & Interviews & $\begin{array}{l}\text { Not indicated in } \\
\text { the abstract }\end{array}$ \\
\hline
\end{tabular}

The dates show that 'language' and 'discourse' are themes important for research. Although the number of works not is big, it is necessary to consider that there are many used words to these terms with similar meanings, such as, voice, story, conceptions, senses, and others. There are a particular relationship methodological context, agreeing with the argument of the authors Berryman and Sauvé (2012):

Language and discourse are also central in research methodologies through 'literature review,' 'interview research,' 'narrative research' or through the study of 'discussions' or 'conversations,' through 'content analysis,' 
'discourse analysis,' 'linguistics,' 'hermeneutics' and 'language research.' (BERRYMAN \& SAUVÉ, 2012: 134).

Our analysis of the occurrence of the study theme of the academic works, based on the descriptors used by the EArte platform, is shown in Figure 1:

Figure 1 - Study theme of the works presenting the word 'discourse' in the title, based on the analysis of the EArte platform

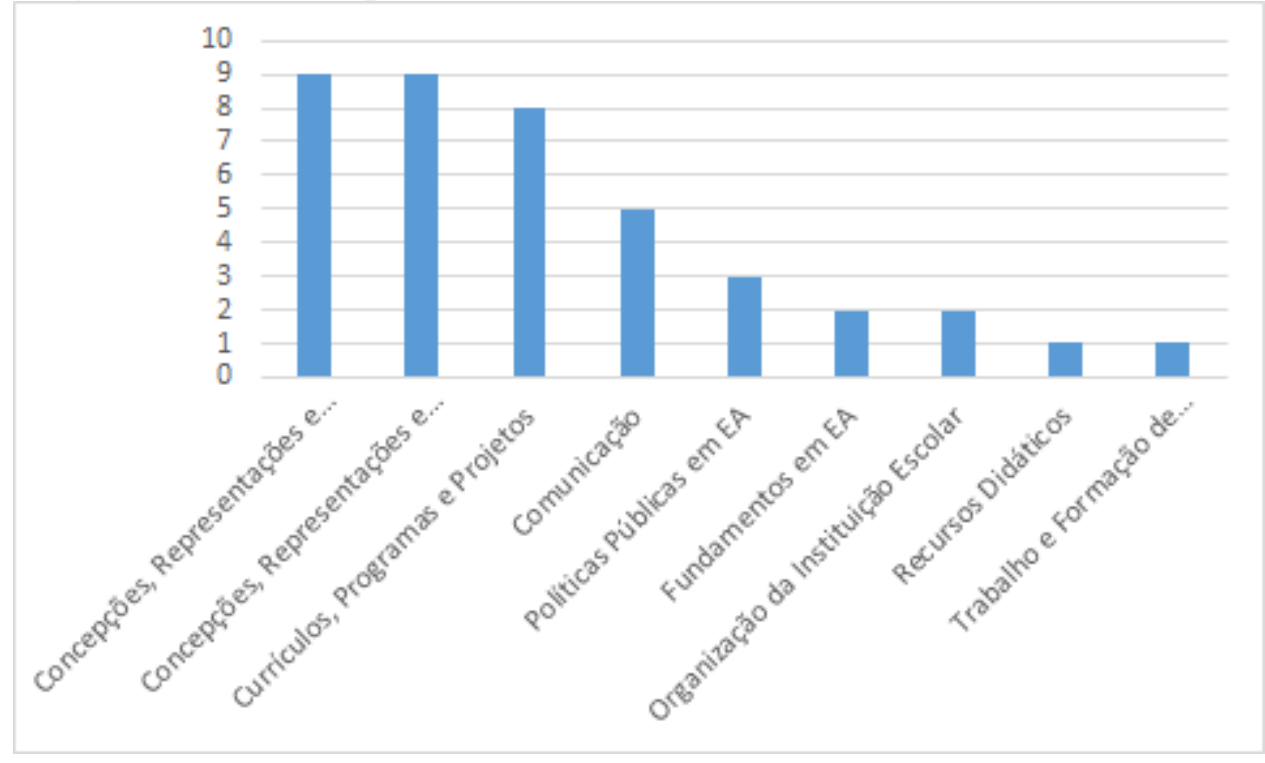

The figure reveals the transversal quality of the 'discourse' theme for research in the area, since the word discourse appears in titles linked to 9 out of the 13 study themes listed in the EArte database, more frequently present in the themes 'Conceptions, Representations and Cognitive Processes of the Instructor in EE' and 'Conceptions, Representations and Cognitive Processes of the Trainee in EE,' followed by 'Curricula, Programs and Projects,' but also showing a strong presence in works that analyze the environmental themes relating to means of social communication and their relations to EE. Attention is also drawn to the presence of works that analyze discourses in legal texts or institutional projects in the context of public policies in EE.

All the studies utilized qualitative methodologies of data collection and analysis, the most frequent being document analysis (media, curricular documents, legislation, etc.), which is present in 12 works, and interviews, present in 10 works. This result is similar to the findings of other studies evaluating production in the area, such as Freitas and Oliveira (2006), who emphasize the vast range of data collection instruments used, especially those designed to obtain qualitative information. As for underlying theoretical frameworks, a large proportion of the abstracts lack any indication. Among those approaches that were indicated are cultural studies, post-structural approaches (whether or not associated with cultural studies), discourse analysis, hermeneutics, critical and emancipatory EE, historical-dialectical materialism, semiotics and psychoanalysis. These theoretical perspectives were cited in our discussions on the theme held at the $13^{\text {th }}$ Invitational Seminar on Environmental Education Research, where we specifically discussed the relation between the 'languages and discourses' theme and research in EE in approaches based on discourse theory (MARTINS et al, 2008), critical and post-critical perspectives (HART, 2005), cultural studies (GUIMARÃES et al, 2012), among others, which have encountered fertile spaces in the field. 
The spaces/subjects producing discourses are also aspects representative of the diversity of the theme in the area. In the analyzed sample, we encounter analyses of discourses produced by academic staff and/or students from basic/higher education (15), curricular documents or legislation (8), the media (7), communities/social actors/urban population (4), researchers (1), projects (1), financial institutions (1) and ecological movement. This observation converges with the investigation of Reigota (2007) into Brazilian theses and dissertations, which indicated that the EE present in the production of knowledge in the area is directed towards various social groups, and also with the findings of Freitas and Oliveira (2006) showing that diverse formative spaces are linked to EE beyond the school.

We concur with Lopes (2006) that "investigating discourses implies investigating the rules that guide practices." Studying the meanings of the different subjects and spaces involved in the production of discourses does not exempt us from seeking to understand the system of relations in which they are embedded. The author also reminds us that discourses "are interwoven with institutions, economic and cultural processes, norms and techniques that constitute social relations."

An important aspect to highlight is that, in Brazilian research in environmental education, discourse is, by itself, a polysemic concept. This polysemy can be illustrated through fragments of some of the abstracts cited below:

The contradictions observed in the discourses arise from theoretical-political, epistemological or ideological disputes existing both in the field and in society itself (Work 9053 - Critical analysis of the discourses present in documents defining environmental education policy in Brazil)

\footnotetext{
...based on the discourse of one of its most important user groups, the Friends of the Wood. (Work 3080 - The discourse of the collective subject and the social representation of the Freguesia Municipal Natural Park: what do the friends of the wood recount?)
}

The data obtained point to a significant gap between the discourse and reality of Environmental Education (Work 4847 - The question of formalism in the official discourse of Environmental Education)

This polysemy of the term can be ascertained when we analyze the different meanings attributed to discourses in research studies in EE by considering the meaning contained in the titles. Pursuing a more detailed analysis, we can observe that discourse is used:

(a) in the context of discourses of people (academic staff and students, researchers, population, community agents), a category that appears in the majority of the works (15), such as, for instance, the works "Sanitary paradigms and environmental problems: the discourses of community health agents" and "Discourses of academic staff on Amazonia: contributions towards teaching Sciences in pursuit of sustainability";

(b) as an adjectivized noun (environmental discourse, ideological discourse, collective discourse, green discourse, social discourse, ecotourism discourse, ecological discourse, educational discourse, legitimizing discourse), a characteristic present in 15 works, such as "Ideological conflicts in the text of Law 9.795/99: an analysis of the ideological discourse in the text of the environmental education law" and "At the margins of the green discourse";

(c) in the context of discourses of documents (curricula, legislation, national or international EE documents, the media), present in five works, such as "Ethics in the discourse of the Zero Hora newspaper on climate changes";

(d) through explicit reference to concepts and authors ('order of discourse,' alluding to Foucault), which appears in two titles: "The order of discourse of Environmental Education." 
These diversity of themes, frameworks and even meanings for the word 'discourse' can be explained by the inherent characteristic of our field of knowledge production, which combines varies conceptions both in the field of research and in intervention initiatives (CARVALHO, 2006; MARTINS et al, 2008).

\section{Final considerations}

In this work we have sought to map and discuss the circulation of the terms language and discourse in the academic production of Environmental Education in Brazil, setting out from the material made available and catalogued on the EArte platform. The analyses were undertaken on the works that cited the words 'language' and/or 'discourse' in the title and the data was obtained by using the classifications of the platform and by reading the abstracts. We recognize that other studies may have concentrated on researching this theme without citing these words in the title. Furthermore, the data was obtained merely from the abstracts. We stress that, as Ferreira (2002) argues:

We need to recognize that abstracts offer a history of academic production through a reality constituted by the abstracts taken as a whole, which is absolutely not the same as what can be narrated through the reality constituted through master's dissertations and doctoral theses, and that could never be the one narrated by the reality experienced by each researcher in his or her research. The abstracts of the analyzed studies recount a certain reality of this production. There will be as many histories on academic production as the number of abstracts (of the same research study) encountered. (Ferreira 2002: 268)

For these reasons, we believe that the study provides a panoramic assessment of the circulation of the terms 'language' and 'discourse' in research in EE, recognizing that other analyses could be made along different analytic lines. For example, it would be possible to explore the relationship between the focus on discourse in research in EE (as demonstrated by the central role in the title) and those study themes related to policies (e.g. LOPES, 2006). The author advocates the productiveness of investigating how curriculum policies "simultaneously develop a process that is global and local, some would say glocal, that imposes determined shared conceptions, but also provides space for reinterpretation, modification, a reading different from pre-established patterns, due to the negotiation inherent to the very process of imposition." However, this analytic deepening requires a more detailed study of complete documents, not just the abstracts of dissertations and theses, with the aim of identifying the possibilities for deconstructing hegemonic discourses on environmental problems and forms of overcoming these through educational action. The results showed that the term 'language' appears infrequently and generally linked to different genres of expression, while the term 'discourse' seems to traverse research in the area in general, found in the titles of works on a diverse range of investigative themes.

We agree with Berryman and Sauvé (2012) when they write that "there are many possibilities venues, angles, approaches and sources of inspiration to address the question of language and discourse in environmental education and environmental education research." We hope to have contributed to deepening the understanding of the diversity and importance of the theme for our area of investigation in EE.

\section{Acknowledgements}

The authors thank Professor Isabel Martins for the orientation and contribution during the process of the construction of the paper and the contributions of the reviewer who performed the critical review. 


\section{Bibliography}

BERRYMAN, T.; SAUVÉ, L., Languages and Discourses of Education, Environment, and Sustainable Development, in International Handbook of Research on Environmental Education ed. Robert B. Stevenson, Michael Brody, Justin Dillon and Arjen E.J. Wals . Routledge Handbooks, 2012, P. 133-146.

CARVALHO, I. C. M. Invenção e auto-invenção na construção psicossocial da identidade: a experiência constitutiva do Educador Ambiental. In: GUIMARÃES, Mauro (ed.).Caminhos da Educação Ambiental da forma a ação. Campinas, SP: Papirus, 2006. p. 31-50.

FERREIRA, N. S. A. As pesquisas denominadas "estado da arte". Educ. Soc. [online]. 2002, vol.23, n.79, pp.257-272.

FISCHER, R. M. B. Foucault e a Análise do Discurso em Educação, Cadernos de Pesquisa, n.114, novembro/2001.

FREITAS, D.; OLIVEIRA, H. T. Pesquisa em educação ambiental: um panorama de suas tendências metodológicas. Pesquisa em Educação Ambiental, São Carlos, v. 1, n. 1, p. 175-191, jul./dez. 2006.

GUIMARÃES, L. B. et al. Tecendo educação ambiental e estudos culturais. Pesquisa em Educação Ambiental, [S.1.], v. 5, n. 2, p. 73-82, july 2012.

HART, P. Transitions in thought and practice: links, divergences and contradictions in post-critical inquiry. Environmental Education Research, 11:4, 391-400, 2005. DOI: 10.1080/13504620500169270

LOPES, A. R. C. Discursos nas políticas de currículo. Currículo sem Fronteiras, v.6, n.2, pp.33-52, Jul/Dez 2006

LOUREIRO, C. F. B. A. Sustentabilidade e educação: um olhar da ecologia política. São Paulo: Cortez, 2012 (coleção questões de nossa época vol. 39)

MARINI, P M M ; MEGID NETO, J. Pós-Graduação e pesquisa em ensino de biologia no Brasil: um estudo com base em dissertações e teses. Ciência \& Educação, v. 17, n. 3, p. 559-578, 2011.

MARTINS, I.; JANSEN, M ; ABREU, T. B. ; SANTOS, L. M. F. . Contribuições da análise crítica do discurso para uma reflexão sobre questões do campo da Educação Ambiental: olhares de educadores em ciências. Pesquisa em Educação Ambiental (UFSCar), v. 3, p. 129-154, 2008.

REIGOTA, M. O estado da arte da pesquisa em educação ambiental no Brasil. Pesquisa em Educação Ambiental, vol. 2, n. 1 - pp. 33-66, 2007.

ROMANOWSKI, J. P.; ENS, R. T. As pesquisas denominadas do tipo "estado da arte" em educação. Diálogo Educ., Curitiba, v.6, n.19, p.37-50, set./dez. 2006. 
SAUVÉ, L. Educación científica y educación ambiental: un cruce fecundo. Enseñanza de las Ciencias, Vol.: 28 Núm.: 1, 2010, p. 5 - 17. 